\title{
The Politics of Curriculum Design in Instructional Communication in Ghana
}

\author{
By Wincharles Coker
}

\begin{abstract}
This paper presents findings from a two-year ethnographic study that explored how institutional politics shaped the curriculum of a graduate program in instructional communication in a Ghanaian public university. Using Porter et al.'s (2000) idea of institutional critique, the research showed that the design of the program was not value-free. The analysis indicated that the curriculum as a textual material promotes preferred literacies that reflect ideologies and core values of its designers. The study found that the instructional communication curriculum is anchored on competencies in applied linguistics and educational psychology. The research advocates the opening of a space crucial for including "new" seminars such as instructional communication, composition studies, and critical theory to the curriculum. The paper makes the case that these new seminars are important for training communication educators to be abreast of the exigencies of the twenty-first century educational enterprise.
\end{abstract}

Keywords: communication, curriculum, education, institution, politics.

\section{Introduction}

In a 2014 editorial of Communication Education, Paul Witt urged colleagues to reimagine the future of communication education. Research in the discipline, he proposed, should henceforth be guided by greater interdisciplinary collaboration with non-American scholars who conduct research outside the United States. Teaching and learning in such contexts, he argued, "deserve more attention from communication education scholars than they have received in the past" (Witt, 2014 , p. 3). Learning about communication education pedagogy from nonAmerican contexts is useful for enriching and broadening knowledge acquisition in the discipline. In particular, the present study satisfies the need to conduct research and build theory grown on African soil. As Nwosu (2014) recently pointed out, "There is a growing discourse in Africa regarding how best to position African scholars as strategic partners and competitors in knowledge production and distribution" (p. 39). Specifically, this work calls attention to the importance of cooperative communication in curriculum design, the role of Afrocentric knowledge systems (e.g., the role of the divine, the amphibious corporeality of the individual, and the non-linearity of time), and the value of local languages in communication education. It must be noted that unlike the West, Africa has little to show for its involvement in communication education research. A number of the countries on the continent have for a long time pursued a media-tropic pedagogy. A media-tropic pedagogy considers the core of communication studies to be mass media-oriented. Taylor, Nwosu and Mutua-Kombo (2004) have blamed this development on four events: (a) the colonial experience (i.e. print journalism was used as a tool for colonization and liberation); (b) the dependence

*Lecturer, Department of Communication Studies, University of Cape Coast, Ghana. 
of psychology-based solutions to media uses and effects; (c) the idea of mass communication as a means of modernization, and (d) the problem of technological determinism (e.g., the role information and communication technologies play in teaching and learning). The authors added that the teaching of introductory classes in human communication in Africa relies on research findings and textbooks that are often unsuitable to explain the African communication experience, and thus called for a shift in paradigm that will "permit better understanding of the African communication environment" (p. 1). One way to learn the Africanness of the curriculum of the communication programs of universities in sub-Saharan Africa is to take the time to examine the content of the curriculum.

Designing a curriculum is complex. Being a technical document detailing pedagogical content, a good curriculum confronts the paradox of consistency and change. Often the more a program's curriculum is presented as an official document spelling out outcomes and expectations to be met, the less responsive it becomes to change. This means that a curriculum is a by-product of thoughtful political tinkering. What goes into selecting a program's content, its structures, and processes are not disinterested. Usually, these pedagogical elements are shaped by the ideologies, power differentials, habits of mind, values, and traditions of program designers and administrators. Curricula, thus, tend to be negotiated deliverables. The forces that shape the design of a program's content, such as those developed by instructional communication scholars, make the idea of a perfect curriculum elusive. This is why Hunt, Wright, and Simonds (2014) recently remarked that the design of communication syllabi still represents a major challenge for the field. According to them, the diverse nature of communication scholarship and its preferences for disparate methods of inquiry require systematic investigations in communication pedagogy to identify a discipline-specific approach to the field. This paper posits that efforts at examining the pedagogical content of communication are crucial for revisiting, in particular, the "missing paradigm problem" (Nainby, 2010, p. 11). This paper contributes to efforts at developing disciplinary knowledge, taking a cue from Witt (2014) who urged scholars to focus more attention on how instructional communication thrives in cultures outside of United States. The goal is to encourage interdisciplinary and intercultural collaboration.

\section{Rationale of the Study}

Using Porter et al.'s (2000) concept of institutional critique ${ }^{1}$, this two-year ethnographic study describes and critiques the curriculum of a graduate program in instructional communication at a large public university in Ghana. ${ }^{2}$ This study will

\footnotetext{
${ }^{1}$ Institutional critique is key for interrogating the interests, ideologies, and core values of program planners and discursive regimes. Porter et al. (2000) posit that the main agenda of institutional critique is to bring about change through reflection, resistance, and revision of textual productions. ${ }^{2}$ Fieldwork was conducted at the University of Cape Coast (UCC), Ghana, between May 2013 and May 2015. Immersion in the site necessitated participation in lectures, departmental seminars, interacted with both faculty and students, using the semi-formal interview method in order to grapple with their lived experiences of the graduate program (Tracy, 2013). Five hours a day
} 
show that as a text, the program's curriculum privileges basic skills or communicative practices that reflect a set of values that are motivated, collectively produced, and historically situated in the institutional traditions of the designers (cf. Bartlett \& Holland, 2002). The author will argue that the dominant values encoded in this curriculum have implications for interrogating the overall quality of the program. The aim of the study is to urge program administrators to reflect on their policy choices and to think about institutional change.

The objective of this study is two-pronged. It describes the structure of a recently accredited graduate program in instructional communication, focusing on its curriculum, and core expectations. Next, it critiques the program's content in order to bring to light its strengths and possible limitations. The study contends that the curriculum is interdisciplinary and fairly praxis-driven, although its philosophy to academic communication is mimetic, employs few critical approaches to pedagogy, and is heavily dependent on Western scholarship. This work emphasizes the graduate program in communication education of this Ghanaian university for two main reasons. The foremost is that the program is targeted at training students to be teachers of the basic communication course. The basic communication course is the "front porch" to many communication departments and programs (Valenzano, Wallace \& Sherwyn, 2014). Potential communication majors as well as students from other disciplines, take their first, and sometimes, only look at the complex phenomenon of communication from the perspective of the basic communication course. To this end, the program is, as Dance (2002) termed it, the "bread and butter" of general education (p. 355). According to Morreale et al. (2006), it is "the most fertile recruiting ground for communication majors and minors" (p. 416). The course is crucial to general education because the academic and professional success of undergraduates heavily depends on it. Hunt and his colleagues (2014) noted that the role of instructional communication should be carefully assessed in the 21 st century because it is "central to the development of the whole person, improvement of the educational enterprise, being a responsible citizen of the world, and succeeding in one's career" (p. 450). The program therefore offers a huge number of graduate teaching instructors and newly appointed faculty in communication departments the opportunity to hone their teaching skills, and to explore new instructional practices.

Second, a programmatic assessment of the graduate program in instructional communication of University of Cape Coast (UCC) is an effort to study the nature of communication education in Ghanaian universities. The program is core to the design of the basic communication course syllabi of other public and private universities, technical universities, the 38 colleges of teacher education, and specialized colleges in the country (Edu-Buandoh, 2015, personal communication). Because UCC is the premier teacher training university in Ghana and one that houses the Institute of Education which superintends all the colleges of education

were spent at UCC's communication department, writing fieldnotes and making sense of the data collected from the department. These include such technical documents as syllabi, memos, minutes of meetings, and other correspondences with accreditation agencies such as the National Council for Tertiary Education and National Accreditation Board in Ghana. 
in the country, it comes as no surprise that many program administrators from other colleges find it convenient to rely on this university for guidance in the development of the basic communication course.

In addressing this concern, the study performs five tasks in the remainder of this paper. First, it sketches out the literature on the basic communication course in North America. Then it presents the architectural narrative of my case study's communication program, its mission, vision, and description of its curriculum. The third section confronts the curriculum by examining its strengths and challenges. The fourth part of the study outlines a set of alternative seminars for enriching instructional communication education in sub-Saharan Africa. Key considerations include courses in critical communication and pedagogy, speech communication, new media and globalization theory, and organizational communication education. The proposal reflects concerns to address special needs in communication education scholarship as the field positions itself to deal with the exigencies of a transcultural 21st century (Hunt et al., 2014). The final strand summarizes findings of the ethnographic study, and makes two recommendations - introduction of "new" seminars and the pursuit of instructional communication research - geared at enhancing instructional communication in Ghana, in particular, and communication education scholarship, in general.

\section{An Overview of the Basic Communication Course}

The history of the basic communication course in North America is often told from its beginning in classical Greek sophistry. Tracing the field to classical Greek rhetoric underscores the mammoth importance of oral communication in the course (Valenzano et al., 2014). Not all scholars, however, agree on what the content of the course should entail. While the classical tradition prefers an education based primarily on Greek oratorical training, logic, and persuasive argumentation, the new school has combined the earlier concerns with literary criticisms. In fact, the confusion these positions exerted on the general education approach, first proposed at Harvard University by Abbot Lowell, led many teachers and administrators to describe this epoch as the "disaster era" (Valenzano et al., 2014, p. 360).

Clearly, avowed allegiances to theories, disciplinary politics, and discrepancies in modes of training have for long affected the design of the basic communication course curriculum. In their 2002 study, Morreale and Backlund remarked that even though communication scholars are generally agreed on a number of courses that tend to be basic to the program (e.g., public speaking, communication theory, and interpersonal communication), the majority do not "agree about what courses should be offered, what courses should be required, or what should be contained in our basic, gateway courses" (Morreale \& Backlund, 2002, p. 2). The researchers traced this difficulty to the diffuse nature of the field. The authors posited that because human communication is a complex phenomenon, communication scholarship will be structurally diverse since it employs different methods of inquiry. These include rhetorical/critical, qualitative/descriptive, and quantitative/ 
predictive approaches. The disparate approaches, Morreale and Backlund stressed, lead faculty to teach and emphasize different skills, competencies, and expectations. It is for this reason that Morreale and Backlund noted that "designers of the communication curriculum need to be creative, and should do so based on (1) their departmental mission, (2) their department's responsibility to their institutional mission, and (3) the strengths of the department's faculty. According to them, a good way to develop a curriculum for communication is to ascertain "the most current consensus of what constitutes the field itself" (p. 6).

Such an inquiry, they argued, is useful for determining what to include in the curriculum, what courses to include for communication majors, and what to require as part of general education. Earlier calls in the special issue of Communication Education made similar remarks (e.g., Allen, 2002; Backlund, 2002; Hunt et al., 2014; Olsen, Weber \& Trimbe, 2002). These scholars emphasized that the curriculum must be clear on whether it aims to offer a liberal, vocational, or specialist education to its learners. Using data obtained from the National Communication Association, Morreale and Backlund (2002) intimated that a communication curriculum needs to emphasize two basic components: basic skills and advanced skills. Basic skills, they explained, are minimal expectations necessary for effective functioning in society and in the workplace. The outcomes of basic skills, they emphasized, must be appropriate to (a) specific audiences, (b) the context enacted, and (c) specific purposes. Advanced skills, on the other hand, should lead students to engage in careful reasoning and competence. Examples include the ability to exhibit inter-personal, inter-group, or inter-cultural communication skills, and the capacity to adapt messages to meet situational needs. Advanced communication skills require the ability to apply, analyze, evaluate, and synthesize disparate kinds of information to suit specific contexts and purposes. In a more democratic educational space, such considerations need to include students' own inputs. In the case of teaching freshmen, advanced skills are necessary for providing them with the opportunity for early enculturation in their academic communities (Bovill, Bulley \& Mors, 2011). Little is, however, known about this concern in the literature.

It is noteworthy that some writers insist that critical analyses of the pedagogical content be given special attention (e.g., Morreale, Hungenberg, \& Worley, 2006; Thompson, 2007; Dannels, Darling, Fassett, Kerssen-Griep, Mottet, Nainby, \& Sellnow, 2014; Valenzano et al., 2014). Echoing Book's (1989) earliest call to explore pedagogical content for communication courses, Hunt and colleagues (2014) stressed that communication education research is broad, and encompasses instructional communication, communication pedagogy, and communication studies. Focusing on K-12 students, Hunt et al. (2014) argued that communication education scholars need to pursue a vigorous research agenda, more than ever, because "communication knowledge and skills are critical to the citizenry and workforce of the 21st century" (p. 453). In their view, strategies for moving the field forward should include pushing state boards of education to adopt endorsements in communication, and should be committed to develop doctoral programs in communication education. As they pointed out, "We as a discipline need to place higher value on the field of communication as a whole by 
supporting efforts to establish more Ph.D. programs that advance instructional communication and communication pedagogy" (p. 458).

Programmatic assessments of communication curricula are also useful for determining the impact of a program in the global society. Brady and José's (2009) study of Michigan Tech's scientific and technical communication (STC) program, for example, shows that the program does not adequately prepare its students to work in linguistically and culturally diverse cultures. This challenge, according to them, needs to be confronted so that students can "develop a more sophisticated knowledge of their own communication practices", as well as, "perceive the movement from local to global as a transition enabling the creation of knowledge and of new learning processes" (p. 42). They maintained that even though the STC program provides opportunities for foreign language literacy, it was optional to students, and that those who studied foreign languages (Spanish, German, Chinese, and French) had few opportunities to make the necessary connections between these languages and their fields of specialization. The results of this frustration, the authors noted, are that students find it difficult to work and compete in international contexts. In resolving this problem, Brady and José proposed a number of solutions. The first is that instructors should carefully describe assignments on international communication and the methodologies that go with them. They also proposed that scholars develop communication across borders that should elicit concerns such as what kind of knowledge outsiders will need in order to join a local STC community, and how cultural and linguistic differences impact the content and organization of a document aimed at providing instructions for performing tasks within a specific cultural setting (Brady \& José, 2009 , p. 53). Other scholars have also suggested that the syllabus be studied not only as an instructional document, but as a socially constructed deliverable whose presentation to students portrays teachers as individuals who are sensitive to students, and are mindful of the power and authority they wield in the class (e.g., Maars, 2006; Thompson, 2007).

In brief, while studies in instructional communication in North America abound, only little is known about the nature of the subject in other cultural contexts such as in sub-Saharan Africa. This study addresses this gap by examining the hidden values in the Master of Arts in instructional communication at UCC, Ghana.

\section{Describing the Program}

The graduate program in instructional communication at this university commenced in June 2013, following approval from the National Accreditation Board (NAB) of Ghana. A two-year summer program, it is one of the graduate programs designed to train human resources in communication competence. The program was birthed out of the need to provide an enabling environment for effective teaching and learning of various aspects of communication, and to engage students in communication research at different levels in a variety of 
modes $^{3}$. The program is an effort by faculty to meet the needs of society by bridging the gap between current realities and future demands. It is a response to calls to train faculty for the basic communication course targeted at freshmen. The program was designed to train teachers of post-secondary education (i.e. polytechnics, teacher colleges of education, specialized colleges) to depart from thinking about communication education as English language education. The training emphasizes that communication is a complex human process that goes beyond language studies. It does so by exposing students to theories and pedagogical approaches underpinning current trends in the basic communication course and praxis of contemporary communication skills. The program is open to graduates with first degrees in communication studies, language-related programs such as English, French, or any Ghanaian languages, and/or those with bachelor's degrees in education. The students are assessed like any other university programs through quizzes, take-home assignments, class tests, group presentations, and endof-semester examinations. The end-of-semester examinations with input from faculty are internally organized. Continuous assessment makes up $40 \%$ of students' grades and end-of-semester examination is $60 \%$.

\section{The Structure of the Curriculum}

The two-year program is organized in two semesters only, each semester representing an academic year. The program comprises cornerstone and capstone modules. As basic skills, the cornerstones represent the foundational seminars in theoretical concepts, appropriate pedagogies, and research methodologies underlying the study and practice of communication education. They are the minimal expectations necessary for achieving competence in teaching the basic communication course. The capstones, or advanced skills, are seminars run to further develop and explore students' interests in specific sub-fields of communication pedagogy. As Morreale and Backlund (2002) pointed out, advanced skills are demanding in the sense that they require high mental learning order capabilities. They require students to analyze, synthesize, and apply concepts in very basic and useful ways to solve practical problems that arise in teaching communication.

Students are required to take four cornerstone seminars and one capstone course for a total of 15 credits for the first semester, and three core courses and two elective courses for a total of 15 credits in the following semester. Though still young, the program has trained its students, using a number of strategies such as lecture methods, group discussions, field trips, seminar presentations, and co-ops. Tables 1 and 2 give a summary of the modules of the program for both first and second years.

\footnotetext{
${ }^{3}$ Consultations with the chair of the department revealed that students' intake has increased from a low of six in 2013 to about 30 in 2015 . The increase was attributed to the growing popularity of the program in the country.
} 
Table 1. A Summary of the Cornerstones

\begin{tabular}{|c|c|c|c|}
\hline Year & Module & Course Description & Credit \\
\hline \multirow[t]{3}{*}{1} & $\begin{array}{l}\text { Theory \& } \\
\text { Practice of } \\
\text { Curriculum } \\
\text { Design and } \\
\text { Development }\end{array}$ & $\begin{array}{l}\text { Exposes students to the theoretical background of } \\
\text { curriculum design and development. Provides } \\
\text { students with practical skills necessary to design } \\
\text { and critique an effective curriculum in the basic } \\
\text { communication course. Helps students to review } \\
\text { contemporary practices in curriculum design. }\end{array}$ & 3 \\
\hline & $\begin{array}{l}\text { Teaching } \\
\text { Foundations of } \\
\text { Communication } \\
\text { Education }\end{array}$ & $\begin{array}{l}\text { Equips students with skills, knowledge, } \\
\text { approaches, and methodologies needed in teaching } \\
\text { the foundations of basic communication. Course } \\
\text { content includes study skills, reading, and } \\
\text { composition pedagogies, oral, and public } \\
\text { presentation skills, general English language use, } \\
\text { and documentation. }\end{array}$ & 3 \\
\hline & $\begin{array}{l}\text { Research } \\
\text { Methods }\end{array}$ & $\begin{array}{l}\text { Endows students with the resources to conduct } \\
\text { their research. Introduces them to the preparation } \\
\text { and presentation of the research proposal, the } \\
\text { different research designs and approaches, } \\
\text { research instruments, the use of data analysis } \\
\text { software such as SPSS, and how to develop an } \\
\text { analytical framework for research, referencing } \\
\text { styles, and thesis writing. }\end{array}$ & 3 \\
\hline \multirow[t]{3}{*}{2} & $\begin{array}{l}\text { Philosophical } \\
\text { and } \\
\text { Psychological } \\
\text { Foundations }\end{array}$ & $\begin{array}{l}\text { Provides students with a general overview of the } \\
\text { history of curriculum conceptualization and } \\
\text { development, and an understanding of the larger } \\
\text { forces that influence the process. Analyzes } \\
\text { philosophical positions on the nature of } \\
\text { knowledge, the function of the school and the } \\
\text { content of the curriculum. Examines and critiques } \\
\text { principles of organizing instruction, derived from } \\
\text { psychological theories of learning, such as } \\
\text { behavioral, cognitive, and social cognitive } \\
\text { theories. }\end{array}$ & 3 \\
\hline & $\begin{array}{l}\text { Communication } \\
\text { in Contexts: } \\
\text { Writing and } \\
\text { Speech }\end{array}$ & $\begin{array}{l}\text { Equips students with skills necessary to identify } \\
\text { and compose good writing and speech. Covers the } \\
\text { basics of communication at meeting, oral } \\
\text { presentation, the art of persuasion, and negotiation } \\
\text { discourse. }\end{array}$ & 3 \\
\hline & $\begin{array}{l}\text { Practicum and } \\
\text { Seminar }\end{array}$ & $\begin{array}{l}\text { Tasks students to teach the basic communication } \\
\text { course under supervision on campus. Students are } \\
\text { required to apply appropriate teaching methods } \\
\text { and theories to reflect on their practice, and } \\
\text { produce a written report. }\end{array}$ & 3 \\
\hline
\end{tabular}

Source: Field Data (2015). 
Table 2. A Summary of the Capstones

\begin{tabular}{|c|c|c|c|}
\hline Year & Module & Course Description & Credit \\
\hline \multirow[t]{3}{*}{1} & $\begin{array}{l}\text { Academic } \\
\text { Communication }\end{array}$ & $\begin{array}{l}\text { Focuses on the use of language in academic } \\
\text { discourse communities. Involves an engagement } \\
\text { with various forms and genres of communication, } \\
\text { and making meaningful contributions in several } \\
\text { academic settings. }\end{array}$ & 3 \\
\hline & $\begin{array}{l}\text { Language Use } \\
\text { in } \\
\text { Communication }\end{array}$ & $\begin{array}{l}\text { Exposes students to the knowledge, use, and } \\
\text { practices of English in both academic and non- } \\
\text { academic communicative events. Areas of } \\
\text { concentration include grammar, vocabulary, } \\
\text { pronunciation, discourse, and pragmatics. }\end{array}$ & 3 \\
\hline & $\begin{array}{l}\text { Theories of } \\
\text { Human } \\
\text { Communication }\end{array}$ & $\begin{array}{l}\text { Surveys major theories in human communication } \\
\text { in relation to its history, philosophy, and } \\
\text { applications. Focuses on mechanistic, } \\
\text { psychological, social constructionist, systemic, and } \\
\text { critical theories to provide a conceptual basis for } \\
\text { understanding interpersonal, group, organizational, } \\
\text { intercultural, and linguistic communication. }\end{array}$ & 3 \\
\hline \multirow[t]{3}{*}{2} & $\begin{array}{l}\text { Interpersonal } \\
\text { and } \\
\text { Intercultural } \\
\text { Communication }\end{array}$ & $\begin{array}{l}\text { Explores communication issues related to } \\
\text { interpersonal contexts such as acquaintanceship, } \\
\text { courtship, and friendship. Highlights how cultural } \\
\text { elements (gender, power, age, status, etc.) } \\
\text { influence the communication process, and } \\
\text { strategies for managing intercultural } \\
\text { communication. }\end{array}$ & 3 \\
\hline & $\begin{array}{l}\text { Business } \\
\text { Communication }\end{array}$ & $\begin{array}{l}\text { Discusses principles and practices of corporate } \\
\text { culture and communicational styles. Examines } \\
\text { how management and staff, businesses, non-profit } \\
\text { organizations, and the media communicate with } \\
\text { one another. }\end{array}$ & 3 \\
\hline & $\begin{array}{l}\text { Scientific } \\
\text { Communication }\end{array}$ & $\begin{array}{l}\text { Exposes students to major skills in scientific } \\
\text { communication. Focuses on information retrieval, } \\
\text { scientific reading and writing, listening and } \\
\text { observing, scientific data interpretation and } \\
\text { representation, scientific argumentation, and } \\
\text { presentation of technical reports. }\end{array}$ & 3 \\
\hline
\end{tabular}

Source: Field Data (2015).

Analysis of the roughly 60 books on the program's reading list show that academic communication is the most dominant literacy; this is closely followed by readings in the foundations of communication pedagogy. Scientific communication and business communication also received considerable attention. Subject areas that are not allocated much reading on the list are research methods and theories of human communication. This observation is worrying because the research methods seminar is considered a core seminar of the program, and theories of human communication one of the key capstone courses. Tables 3, 4, and 5 catalog the reading list based on subject areas. 
Table 3. Basic Texts for Academic Communication and Foundations of the Basic Communication Course

\begin{tabular}{|l|l|l|l|}
\hline Author & Book & Date & Publisher \\
\hline Biber, D. & Variation across speech and writing & 1998 & $\begin{array}{l}\text { Cambridge } \\
\text { University Press }\end{array}$ \\
\hline Bizell, P. & $\begin{array}{l}\text { Academic discourse and critical } \\
\text { consciousness }\end{array}$ & 1992 & $\begin{array}{l}\text { University of } \\
\text { Pittsburgh }\end{array}$ \\
\hline Campbell, C. & $\begin{array}{l}\text { Teaching second-language writing: } \\
\text { Interacting with text }\end{array}$ & 1998 & Heinle \& Heinle \\
\hline $\begin{array}{l}\text { Canagarajah, } \\
\text { A. S. }\end{array}$ & A geopolitics of academic writing & 2002 & $\begin{array}{l}\text { University of } \\
\text { Pittsburgh }\end{array}$ \\
\hline $\begin{array}{l}\text { Crystal, D. \& } \\
\text { Davy, D. }\end{array}$ & Investigating English style & 1969 & $\begin{array}{l}\text { Indiana } \\
\text { University of } \\
\text { Press }\end{array}$ \\
\hline $\begin{array}{l}\text { Ferris, D. \& } \\
\text { Hedgecock, J. } \\
\text { S. }\end{array}$ & $\begin{array}{l}\text { Teaching ESL composition: purpose, } \\
\text { process, and practice }\end{array}$ & 1998 & $\begin{array}{l}\text { Lawrence } \\
\text { Erlbaum }\end{array}$ \\
\hline $\begin{array}{l}\text { Flowerdew, J. } \\
\text { \& Peacock, M. }\end{array}$ & $\begin{array}{l}\text { Research perspectives } \text { on English for } \\
\text { academic purposes }\end{array}$ & 2001 & $\begin{array}{l}\text { Cambridge } \\
\text { University Press }\end{array}$ \\
\hline Hyland, K. & $\begin{array}{l}\text { Disciplinary discourse: Social } \\
\text { interactions in academic writing }\end{array}$ & 2000 & Longman \\
\hline Jordan, R. R. & $\begin{array}{l}\text { English for academic purpose: A guide } \\
\text { and resource book for teachers }\end{array}$ & 1997 & $\begin{array}{l}\text { Cambridge } \\
\text { University Press }\end{array}$ \\
\hline Johnson, K. & $\begin{array}{l}\text { Understanding language teaching: } \\
\text { Reasoning in action }\end{array}$ & 1999 & Heinle \& Heinle \\
\hline $\begin{array}{l}\text { Mackey, A. \& } \\
\text { Gass, S. M }\end{array}$ & $\begin{array}{l}\text { Second language research methods and } \\
\text { design }\end{array}$ & 2005 & $\begin{array}{l}\text { Lawrence } \\
\text { Erlbaum }\end{array}$ \\
\hline Mauranen, A. & $\begin{array}{l}\text { Cultural differences in academic } \\
\text { rhetoric }\end{array}$ & 1993 & Peter Laing \\
\hline $\begin{array}{l}\text { Swales, J. M. } \\
\text { Genre analysis: English in academic } \\
\text { and research settings }\end{array}$ & 1990 & $\begin{array}{l}\text { Cambridge } \\
\text { University Press }\end{array}$ \\
\hline $\begin{array}{l}\text { Swales, J. M. Feak, C. B } \\
\text { \& Feak, C. B }\end{array}$ & $\begin{array}{l}\text { Essential tasks and skills } \\
\text { English in today's research world: A } \\
\text { writing guide }\end{array}$ & 2000 & $\begin{array}{l}\text { University of } \\
\text { Michigan Press }\end{array}$ \\
\hline Soure:Fichiga Press
\end{tabular}

Source: Field Data (2015).

Clearly, analysis of the reading list shows that the fulcrum of this communication program is language. The designers of the program have broadened competencies in this area to cover five main concentrations in applied linguistics. These are text linguistics (e.g., Biber, Campbell, Crystal \& Davy), discipline-specific writing (e.g., Hyland), critical academic writing (e.g., Bizell, Canagarajah, Mauren), genre analysis (e.g., Swales, Swales \& Feak), and English as a Second Language/English for Academic Purposes (e.g., Ferris \& Hedgecock, Flowerdew \& Peacock, Jordan, Johnson, and Mackey \& Gass). The heavy emphasis on language is justifiable because the basic communication course, over the years, has been considered as a remedial course in the English language though there have been suggestions to move beyond this fixation (Dzameshie, 1997; Fukerson, 2005; Afful, 2007). 
From a critical perspective, one realizes that the graduate program in communication pedagogy privileges core competencies in language studies because a significant number of the program's designers are scholars with a language-based background. Yet while language education plays a very important role in communication pedagogy, it is necessary to point out that the language ideology could, however, lead the graduate student to believe that in order to be an effective teacher in the basic communication course, they have to master the field of applied linguistics. The implication of this assumption is that literacies and competencies in instructional communication, critical communication pedagogy, and rhetorical approaches critical in communication pedagogy may be less important. The story looks different, however, when texts in curriculum design and human communication are added. Besides the fact that the texts need to be updated, they are fairly basic and core to a comprehensive understanding of the theories of curriculum design and development (e.g., Grundy, Ross, Tannen \& Tannen, Wiles \& Bondi), and also expose students to the basic concepts of human communication (e.g., Heath, Littlejohn, Scollon \& Scollon) as can be seen in Table 4.

Table 4. Basic Texts for Curriculum Design and Human Communication

\begin{tabular}{|l|l|l|l|}
\hline Author & \multicolumn{1}{|c|}{ Book } & Date & Publisher \\
\hline Grundy, S. & Curriculum: Product or praxis & 1987 & $\begin{array}{l}\text { Falmer } \\
\text { Press }\end{array}$ \\
\hline Ross, A. & Curriculum: Construction and critique & 2000 & $\begin{array}{l}\text { Falmer } \\
\text { Press }\end{array}$ \\
\hline $\begin{array}{l}\text { Tannen, D. } \\
\text { \& Tannen, L. }\end{array}$ & $\begin{array}{l}\text { Curriculum development: Theory into practice } \\
\text { (4th ed.) }\end{array}$ & 2007 & $\begin{array}{l}\text { Allyn \& } \\
\text { Bacon }\end{array}$ \\
\hline $\begin{array}{l}\text { Wiles, J. \& } \\
\text { Bondi, J. }\end{array}$ & Curriculum development: A guide to practice & 1993 & Macmillan \\
\hline $\begin{array}{l}\text { Wilmot, S. } \\
\text { W. }\end{array}$ & $\begin{array}{l}\text { The Allyn \& Bacon teaching assistants } \\
\text { handbook: A guide for graduate instructors of } \\
\text { writing and literature }\end{array}$ & 2003 & Longman \\
\hline $\begin{array}{l}\text { Heath, R. L. } \\
\text { Human communication: Theory and research } \\
\text { concept, context and challenges }\end{array}$ & 2000 & $\begin{array}{l}\text { Lawrence } \\
\text { Erlbaum }\end{array}$ \\
\hline $\begin{array}{l}\text { Littlejohn, S. } \\
\text { W. \& Foss, } \\
\text { K. A. }\end{array}$ & Theories of human communication (9th ed.) & 2008 & $\begin{array}{l}\text { Thomson } \\
\text { Wadsworth }\end{array}$ \\
\hline $\begin{array}{l}\text { Scollon, R. } \\
\text { \& Scollon, S. }\end{array}$ & Intercultural communication & 1995 & Blackwell \\
\hline
\end{tabular}

Source: Field Data (2015).

The capstone seminars in business communication and scientific communication are also commendable. They satisfy calls to make the basic communication course applicable to the business work environment (Morreale \& Backlund, 2002; Hunt et al., 2014). As the global community is increasingly a technoculture, it is important that the graduate program exposes students to the complexities involved in communicating in business and scientific contexts. 
Table 5. Basic Texts for Business and Scientific Communication

\begin{tabular}{|l|l|l|l|}
\hline Author & Book & Date & Publisher \\
\hline Guffey, M. E. & $\begin{array}{l}\text { Business communication: process and } \\
\text { product (4th ed.) }\end{array}$ & 2003 & $\begin{array}{l}\text { South-Western } \\
\text { Thomson } \\
\text { Learning }\end{array}$ \\
\hline $\begin{array}{l}\text { Lehman, C. } \\
\text { M. \& Debbie, } \\
\text { D. }\end{array}$ & Business communication (13th ed.) & 2002 & $\begin{array}{l}\text { South-Western } \\
\text { Thomson } \\
\text { Learning }\end{array}$ \\
\hline $\begin{array}{l}\text { Rouse, M. J. } \\
\text { \& Rouse, S. }\end{array}$ & $\begin{array}{l}\text { Business communications: } \text { A cultural and } \\
\text { strategic approach }\end{array}$ & 2002 & $\begin{array}{l}\text { South-Western } \\
\text { Thomson } \\
\text { Learning }\end{array}$ \\
\hline $\begin{array}{l}\text { Thill, J. V. \& } \\
\text { Bovee, C. L. }\end{array}$ & $\begin{array}{l}\text { Excellence in business communication (4th } \\
\text { ed.) }\end{array}$ & 1999 & Prentice Hall \\
\hline $\begin{array}{l}\text { Gregory, J. \& } \\
\text { Miller, S. }\end{array}$ & $\begin{array}{l}\text { Science in public communication, culture } \\
\text { and credibility }\end{array}$ & 1998 & Plenum Press \\
\hline $\begin{array}{l}\text { Martin, J. R. } \\
\text { \& Veel, R. }\end{array}$ & $\begin{array}{l}\text { Reading science: } \text { Critical and functional } \\
\text { perspectives } \text { on discourse of science }\end{array}$ & 1998 & Routledge \\
\hline Prelli, L. & $\begin{array}{l}\text { A rhetoric of science: } \text { Inventing scientific } \\
\text { discourse }\end{array}$ & 1989 & $\begin{array}{l}\text { University of } \\
\text { South Carolina } \\
\text { Press }\end{array}$ \\
\hline
\end{tabular}

Source: Field Data (2015).

In the next section, we turn our attention to an analysis of the curriculum of the program. This will involve identifying the strengths of the curriculum and establishing its potential limitations.

\section{Critiquing the Program}

\section{Strengths}

The graduate program in communication education of the University of Cape Coast is anchored on three major pillars. It is interdisciplinary, cognitivist, and practice-driven. The program, first and foremost, was designed based on the competencies of faculty from three departments: language, communication, and education. Observations of the curriculum's structure shows that the program emphasizes, in the first year, competencies in theories and concepts of educational foundations, followed by knowledge and practice in applied linguistics. The final year exposes students to major fields in communication education to encourage them to specialize in any of the branches.

The interdisciplinary structure of the program is commendable because faculty teach and can teach best what they have studied. Or as Morreale and Backlund (2002) said, the design of a program must be cognizant of faculty's strengths in the context of the institutional mission and vision. In this light, the cornerstones and capstones of the program are structurally social science-based and language-oriented respectively. The first year of the program offers graduate 
students a robust foundation on Hilda Taba's models ${ }^{4}$ of curriculum design and development and the postpositivist paradigm. The second seminar, Teaching Foundations of Communication Education, also treats communication education as academic literacy. This focus, in my view, is emic and context-sensitive because it accounts for the communicative needs of tertiary students as second language speakers. The seminar exposes graduate students to theoretical and pedagogical implications underlying the teaching and learning of English for Academic Purposes (EAP) in general, and academic communication. Using a number of approaches from grammatical and communicative competence theories, needs analysis, discourse analysis, and error analysis, faculty equip communication teacher-trainees to critically assess fundamental concepts-remediation, foundationalism, generalist $v s$. disciplinary writing - involved in the teaching of the basic communication course to undergraduate students.

Because of the demands the program places on students, we may suggest that the curriculum is cognitivist in nature. It assumes, $a b$ initio, that to train good teachers of the basic communication course, teacher-trainees need to be thoroughly taught theories of learning and memory work. In this regard, emphasis has been placed on how to design and develop a curriculum and the forces that shape it. The planners of the program have also ensured that students gain basic skills in the theory and praxis of communication education in an environment where English is learnt as a second language. Interestingly, the pedagogical content of the first year of the program is not disinterested. As a matter of fact, it is an accretion of knowledge systems, assumptions, and ideologies of the designers themselves. Given that literacies are usually context-dependent (Barton, 2001; Bartlett \& Holland, 2002; Street, 2003), it comes as no surprise that faculty from education and language backgrounds who are the architects of the program considered the core content of the formative year to be education- and languagebased. When seen as workplace practices of the faculty involved, we realize that these practices are, indeed, wrapped in power structures; they are rooted in the cultures, traditions, and histories of their institutional settings. It is on the basis of the privileged positions the designers of the program enjoyed that they elected to draw up the curriculum the way they did, although they may have considered what Brandt and Clinton (2002) termed localizing moves and globalizing connections. That is, they may have ensured that they satisfied local conditions that give rise to the relevance of the program, and yet they may have also taken into account the nature of the program on the international scene. The latter assumption, unfortunately, was not always the case, as will be shown shortly.

A similar argument may be made about the capstones of the program. With the exception of seminars in theories of human communication, business communication, and scientific communication, much space, again, is allotted to

\footnotetext{
${ }^{4}$ Taba's model is commonly used by administrators to develop curricula. In her 1962 book, Curriculum Development, Theory and Practice, Taba argued that curriculum design should be guided by seven basic rationales or steps: 1 . Diagnosis of needs; 2 . Formulation of objectives; ${ }^{3}$ Selection of content; 4. Organization of content; 5. Selection of learning experiences; 6. Organization of learning experience, and 7. Determination of what to evaluate and how (Taba, 1962, p. 12).
} 
students with strong backgrounds in applied linguistics. The designers of the program, however, made efforts to allow for specialization. Analysis of the capstones shows that students could specialize in one of the three concentrations: (a) academic communication, (b) business communication, and (c) scientific communication. Though it is not clear how the seminars in language use in communication and interpersonal/intercultural communication fall under these sub-fields, it can be said that they serve more or less as theoretical explorations into any of the identified subject areas. With the exception of academic communication that looks like a sequel to the first-year seminars in teaching the foundations of communication education, areas such as business communication, scientific communication, and interpersonal or intercultural communication do not. Their introduction in the second year may be useful for specialization purposes, though the effort compromises the principle of continuity in curriculum development.

The theoretical weight of the program is tested in practice as well. It has a slot for teaching practice and demonstrations. When the author was first consulted to design this three-hour credit seminar in May 2013 as part of a reconnaissance field trip to Ghana ${ }^{5}$, it was designed on the assumption that knowledge for effective teaching is strategic. In making this conceptual assumption a reality, the program exposed the students in the program to basic theories of argumentation to equip them with skills needed in presenting their subject matter to their prospective students. The seminar also covered the relevance of basic teaching strategies such as the lecture, Socratic, discovery, and discussion methods. The graduate class was encouraged to make oral presentations, using Prezi, Powerpoint, and extempore modes. Besides the seminar on practice, the program also made room for learner acculturation. And because the department hosts the basic communication course as a university-wide requirement for all freshmen, it offered interested graduate students the opportunity to observe and participate in the quality assurance system of the basic communication course. This includes but is not limited to the following:

1. Graduate teaching instructorship;

2. Periodic meeting of instructors to peer-review a common course syllabus;

3. Peer-review of a common assessment rubric;

4. Administration of a common mid-semester general quiz;

5. Administration of a common end-of-semester examination;

6. Team-based grading.

Now we turn our attention to the possible limitations of the program. Mention must be made of some of the institutional constraints facing the university and the communication department housing the program. An analysis of the department's strengths, weaknesses, opportunities, and threats (SWOT) by the administrators of the program clearly shows that although it has a dedicated staff that enjoys a good interpersonal relationship, has a reasonable number of teaching and learning equipment, and attracts a high student enrolment, the department is, nonetheless,

\footnotetext{
${ }^{5}$ The author was then a doctoral candidate in a mid-west university in the United States of America.
} 
confronted with inadequate lecture room facilities and office space for faculty. The mission of the department is also frustrated by a dwindling budget support and inadequate number of faculty with expertise in various sub-fields of the communication program.

\section{Limitations}

Four main challenges confront the program. First, the department's writing model tends to be formalistic and mimetic. The program's curriculum indicates that there is heavy emphasis on formalism. As was confirmed by two participants during the interview sessions, the language components of the program draw inspirations mainly from form-based writing. Because a formalistic philosophy of communication or writing is one that privileges form as a major characteristic of text (Fulkerson, 1979), it explains why the program places much emphasis on the type of genre analysis that stresses the rhetorical canon of arrangement or structure.

This type of genre analysis identifies the communicative functions specific to a genre by focusing mainly on the form or structure that typifies the genre. However, too much emphasis on form as the marker of directness and clarity of thought could render instructors' approach to the basic communication course overtly mimetic. Mimetic communication or writing is one that holds that there is a clear connection between good writing and good thinking. As one of the interviewees noted, this kind of writing hardly promotes creativity and imagination. Mimetism makes communication formulaic. It enjoins writers to follow a rigid structure by first announcing their intent and by meticulously supporting it with evidence. In the case of the department studied, this philosophy requires that students first begin their productions (usually expository essays) with a thesis statement, and then develop the thesis in manageable chunks of organized paragraphs. At the paragraph level, they are equally expected to manage the organizational flow of their thoughts by arranging their arguments according to a topic sentence, major support, and minor support sentences. The problem with this process is that it makes communication mechanical, and envelops its inherent messiness. The direct participant observations of the department's pedagogical approaches over the last decade and analysis of its assessment documents show that the basic communication course values a five-paragraph essay composed in the manner described above.

Argumentative, narrative, and descriptive genres in the basic communication course are taught from this formalistic principle. This choice may have been privileged because it is believed to be economical for both faculty and students. Because the course is taught in over 50 sessions by a dwindling faculty force due to reduced administrative support, faculty often explain that the large class sizesusually not less than 50 students - make the adoption of other approaches burdensome in terms of grading. Less emphasis is laid on the strategic or rhetorical relevance of communication in the program. For instance, the program does not teach the basic PACT (purpose, audience, context, text) principles (Fulkerson, 2005). Given that the designers have placed too much emphasis on form, other 
skills such as speaking play second fiddle to writing. The only seminar in speech in the curriculum is also taught from a comparative perspective with writing. Here again, the seminar employs a genre analysis approach by which instructors compare the features and modes of writing and speech.

Second, the impact of the graduate program on the basic communication course of freshmen is not direct. One may dare ask, is there a disconnect between what is taught at the graduate level and what is actually practiced in the basic communication course syllabus? For example, one of the key ingredients on the basic communication syllabus at the university that was the focal point of this study was grammar. And yet, descriptive grammar is not a core subject in the graduate program. Another core element on the university's basic communication course syllabus is the four basic forms of writing (expository, narrative, argumentative, and descriptive) as well as other genres of business writing (résumé, job application, and permission letters). Composition theory does not make the list of seminars in the graduate curriculum. This omission may be attributed to challenges by the communication department to periodically conduct needs analysis or usability studies among its students (cf. Morreale, et al., 2006). Constant research into the needs of students of the basic communication course is of mammoth importance because it has the potential of providing faculty, program administrators, and curriculum designers with relevant information necessary to understand the learning requirements of students. Such an approach democratizes the learning process, and makes it much more learner-centered. As a Ghanaian curriculum scholar noted:

Not until the teacher knows the needs of his/her students, he/she cannot plan a teachable lesson. The difficulty of the material to be covered, and the amount of material to be learned must be determined by the teacher in relation to the abilities of the individuals to be taught or reached. (Ababio, 2009, p. 2)

A report submitted to the communication department in 2011 summarizes the results of a survey conducted among 240 students of the basic communication course. Even though the majority of the respondents felt that oral communication is an indispensable skill in communication, such a need is yet to be included in the syllabus (Gborsong, Afful, Coker, Osei, Twumasi, \& Baiden, 2015). However, oral communication is considered the backbone of the basic communication course in North America (Morreale \& Backlund, 2002; Hunt et al., 2014; Valenzano et al., 2014), and a separate basic course in composition addresses the written component.

Third, the curriculum has little space for critical communication theory and critical pedagogy. Though the program equips students with skills for reflecting on their own practices as student-teachers, it is difficult to determine how this objective is successfully met. In view of the absence of studies in critical communication and critical pedagogy, we may wonder how graduate students of the program are made to reflect on the implications of their pedagogical choices. As this paper argues, knowledge construction, and how it is communicated to students is not value-neutral. As a practice situated in the classroom, teaching basic communication to freshmen cannot escape questions of power asymmetry, 
ideology, and gender. The classroom is a contact zone where different cultures grapple with each other (Pratt, 1991). Issues of power in this space constantly need to be negotiated on horizontal and vertical planes. Gary Olson (1998) reminds us that the classroom is a contact zone where some students are marginalized. Such critical theories as postcolonial theory, for example, can provide us with a useful lens to illuminate how colonial impulses come into play between teachers and students; comprehend how epistemic violence operates in the classroom on both political and psychological levels, and deconstruct systems of domination among students and how teacher talk and choices can reinforce the colonization and marginalization of subaltern/minority students.

Critical theories can expose the communication teacher to how the subaltern student copes with the 'imperialist' teacher in order to gain legitimacy and acceptance. For Olson (1998), the focus should not be the mere promotion of multivocality but instead how the voices of the marginalized are ideologically represented. It should not be mere intellectual tourism, as he puts it. Olson's article raises some concerns for me as a faculty member. To be sure, it has sharpened my consciousness and personal experiences of classroom politics with respect to contact zones and postcolonial theory. And yet a radical position is that the application of postcolonial theory to the classroom can embolden students to be rebellious, express signs of anarchy, and pose a threat to teacher authority. As an international student, the author observed that professors seemed to place us to a subaltern position. In some instances their posture was condescending as if to say that "You know what? These theories and concepts are about us; they're ours, and so shut up and listen!"

Teachers, thus, need to manage their authority and power in a manner so that they do not stand in the way of students' active participation in the learning process. This resolve includes dealing with sensitive or potentially embarrassing topics, assigning tasks fairly, asking appropriate questions, ensuring a balance in students' engagement and gender as well as knowing when and how to give rewards and punishment. Thompson (2007) reminds us that often teachers worry that a more flexible, democratic, open climate can undermine their authority. At the same time, instructors would have to ensure that students do not burden one another or show dominance over less powerful ones. Chory and Goodboy (2010) draw our attention to different issues in student resistance and compliance as well the basis of instructors' power in the classroom. These include coercive power, legitimate power, reward power, expert power, and referent power. Seminars that expose graduate students to the underlying currents of their choices in the classroom should be encouraged in the curriculum.

The content of the curriculum is also heavily dependent on Western scholarship and not so well anchored in indigenous knowledge systems. Focus group assessments completed by the author show that reliance on international systems of knowledge is very important. It gives teachers and program administrators in Ghana the opportunity to learn from best practices. However, the ideology of best practices upheld by the curriculum developers has the potential of slowing the pace of research in Afrocentric communication and pedagogy. Teaching graduate students the practice of communication pedagogy from an 
Afrocentric perspective is not only important for asserting the distinctiveness of communication education in Africa. It is an attempt, to emphasize how teaching should be context-bound. This envisaged educational system acknowledges the values of how knowledge is imparted to its people. This restates one of the resolutions of the Cape Town conference of African communication scholars which stressed that curriculum developers should be cognizant of the social and cultural contexts existing on the African continent (Odhiambo, Boafo, Aznar, McClain \& Sy, 2002). The proposal is a call to ensure that the goal of rolling out a pan-African coordination of education lead to a broader understanding of social and cultural contexts shaping communication education on the continent. And yet while it is not desirable to promote a model of communication solely based on African epistemologies, the goal is to draw from the rich pedagogical traditions of Africa in developing the communication curriculum will be a move toward hybridizing the program. The more such proposals are accepted the easier it will be for African communication scholars to position themselves, Nwosu (2014) noted, "as strategic partners and competitors in knowledge production and distribution" (p. 11).

\section{Proposing a "New" Curriculum}

As the designers and developers of the program seek ways to review the curriculum, designers should pay attention to two main issues. These are (1) the introduction of foundational seminars and (2) the pursuit of communication pedagogy research. It is important that seminars such as introduction to rhetorical communication, critical pedagogy, instructional communication, and new media and globalization studies, speech communication, and organizational communication education be included in the curriculum. Studies into rhetorical communication can replace the seminar in academic communication. Waldeck, Plax, and Kearney's (2010) systematic review of instructional communication research published from 1970 to 2010 explains that concentrations in this field have been on theories such as student comprehension apprehension, student motivation, on the one hand, and instructor confirmation and instructor misbehaviors, on the other hand. Research in rhetorical communication, critical pedagogy, instructional communication, and speech communication may enable graduate students of communication pedagogy to be better placed to teach the core of the syllabus: communication competence. Because this skill is taught based on the formalist principle, a rhetorical approach to academic writing will expose students to ways of enriching their writing and make it imaginative and audiencespecific.

Further, courses in critical pedagogy and instructional communication can replace the seminars in assessment of communication skills and practicum respectively. This is important for exposing students to the cultural politics of teaching in the classroom as a contested site. The seminars should enable students to draw on pedagogical methods appropriate for teaching the basic communication course. Thompson (2007), in particular, speaks of welcoming strategies, tension balancing strategies, and presentational strategies that are needed to present the 
basic communication course syllabus to freshmen. A seminar on oral communication should be useful in making freshmen not only skillful in writing but also strategic in speaking and listening. As oral communication is the backbone of the basic communication course in many American universities (Allen, 2002; Valenzano et al., 2014), an addition of this course to the syllabus in African universities and colleges will be desirable as society has become intricately global. Based on the analysis above, it seems advisable to create a twoyear curriculum communication education in sub-Saharan Africa in general, and Ghana, in particular (Table 6).

Table 6. A Proposed Two-Year Master of Arts in Communication Education Program Structure

\begin{tabular}{|l|l|c|}
\hline Year 1 & \multicolumn{2}{|l|}{} \\
\hline Code & Foundational Courses & Credit \\
\hline MCE 501 & Theory and Practice of Communication Education & 3 \\
\hline MCE 502 & $\begin{array}{l}\text { Teaching Foundations of Instructional } \\
\text { Communication }\end{array}$ & 3 \\
\hline MCE 503 & Interdisciplinary Research Strategies & 3 \\
\hline MCE 502 & Critical Communication and Pedagogy & 3 \\
\hline & Special Courses & 3 \\
\hline MCE 503 & Advanced Composition Theory and Practice & 3 \\
\hline MCE 504 & Introduction to Speech Communication & 3 \\
\hline MCE 505 & New Media Theory & 3 \\
\hline MCE 506 & Communication Education for Social Justice \\
\hline
\end{tabular}

Students will be required to take three (3) core courses and one (1) elective course for a total of twelve (12) credits for the semester.

\begin{tabular}{|l|l|c|}
\hline Year 2 & & \\
\hline Code & Foundational Courses & Credit \\
\hline CME 507 & International Communication and Globalization Studies & 3 \\
\hline CME 508 & Critical Approaches to Practicum \& Seminar & 3 \\
\hline CME 509 & Humanistic Assessment in Communicative Education & 3 \\
\hline & Special Courses & 3 \\
\hline CME 510 & Organizational Communication Education & 3 \\
\hline CME 512 & Advanced Communication Theory & 3 \\
\hline CME 513 & Critical Rhetorical Studies & 3 \\
\hline CME 514 & Afrocentric Communication Theory \& Pedagogy & 3 \\
\hline CME 515 & Introduction to International Communication Education & 3 \\
\hline CME 516 & The Art of Public Speaking & \\
\hline
\end{tabular}

\section{Conclusion}

In this work, the study maintains that the development of a curriculum is not value-free. The graduate program in instructional communication at the University 
of Cape Coast is not disinterested. The analysis showed that the curriculum as a textual material promotes preferred literacies that reflect the ideologies and core values of its designers. The basic skills to be mastered by graduate students of the program are in the domain of language studies and applied linguistics. This value represents the interest of faculty-administrators drawn from key fields of the linguistic discipline because they are the principal architects of the program. My analysis also showed that the program is, nonetheless, interdisciplinary; it draws expertise from language, education, and communication faculty. Besides the emphasis on applied linguistics, the curriculum embraces knowledge systems from the social sciences (e.g., theory of curriculum design, psychological foundations of curriculum) and communication studies (e.g., theories of human communication, interpersonal/intercultural communication). The program is also based on knowledge acquisition, and makes room for praxis. Students are given the opportunity to practice what they have learnt in class during oral presentations, and are also made to practice teaching first year students as part of their training.

The ethnographic study shows that the graduate program is confronted with three main challenges. In the first place, its approach to communication is formulaic. Its perspective to writing, in particular, makes students not so imaginative in their productions. Too much emphasis on writing takes attention away from other literacies and competencies such as public speaking, reading, and listening. Second, there is a seeming disconnect between what is taught at the graduate level, and what is practically taught in the basic communication course at the undergraduate level. Some interviewees for this study said the disconnect may be due to difficulties in conducting usability studies or impact assessment research. Third, the program's content is intensively Western-centered. Efforts at introducing epistemologies that hail from the African continent are yet to be seen.

The complexities of communication pedagogy call for a concerted research agenda. If graduate education in this field is to make the needed impact, then, teachers, scholars, and program administrators should embark on vigorous studies about the nature of communication education. Hunt et al. (2014) suggested that such efforts should seek ways to address the best methods for addressing specific communication-related instructional strategies such as collaboration, discussion, experiential activities, and group work. They also recommended the need to integrate communication theory and pedagogy. Such efforts need to begin with formal needs assessments studies of stakeholders, such as students and their prospective employers. Such studies may be guided by questions Morreale and her colleagues (2006) posed a decade ago: Does the basic course meet students' needs professionally and personally? What about surveying employers? Does the basic course satisfy what employers expect in college graduates? How does the basic course need to change to meet academic, theoretical, and skills needs identified by various stakeholders? 


\section{References}

Ababio, B. T. (2009). Identifying students' background and needs for effective teaching at the University of Cape Coast. Drumspeak: International Journal of Research in the Humanities, 2(2), 1-27.

Afful, J. B. A. (2007). Academic literacy and communicative skills in the Ghanaian university: A proposal. Nebula, 4(3), 141-159.

Allen, T. (2002). Charting a communication pathway: Using assessment to guide curriculum development in a re-vitalized general education plan. Communication Education, 51(1), 26-39.

Backlund, P. (2002). What should we teach and how should we teach it? Communication Education, 51(1), 1-17.

Bartlett, L., \& Holland, D. (2002). Theorizing the space of literacy practices. Ways of Knowing Journal, 2(1), 10-22.

Barton, D. (2001). Directions for literacy research: Analyzing language and social practices in a textually mediated world. Language \& Education, 14(2/3), 92-104.

Bovill, C., Bulley, C. J., \& Morss, K. (2011). Engaging and empowering first-year students through curriculum design: Perspectives from the literature. Teaching in Higher Education, 16(2), 197-209.

Brady, A., \& José, L. (2009). Writing for an international audience in a US technical communication classroom: Developing competence to communicate knowledge across cultures. Nordic Journal of English Studies, 8(1), 41-60.

Brandt, D., \& Clinton, K. (2002). Limits of the local: Expanding perspectives on literacy as a social practice. Journal of Literacy Research, 34(3), 337-356.

Chory, R. M., \& Goodboy, A. K. (2010). Power, compliance, and resistance in the classroom. In D. L. Fassett \& J. T. Warern (Eds.), The Sage handbook of communication and instruction (pp. 181-200). Los Angeles and Washington DC: Sage.

Dance, F. E. X. (2002). Speech and thought: A renewal. Communication Education, 51, 355-359.

Dannels, D. P., Darling, A., Fassett, D. L., Kerssen-Griep, J., Mottet, T. P., Nainby, K., \& Sellnow, D. (2014). Inception: Beginning a new conversation about communication pedagogy and scholarship. Communication Education, 63(4), 366-382.

Dzameshie, A. (1997). Towards a communicative approach to teaching English as a second language in Ghana. In M. E. Kropp Dakubu (Eds.), English in Ghana (pp. 173-194). Accra: Ghana Universities Press.

Fulkerson, R. (2005). Composition at the turn of the twenty-first century. College Composition and Communication, 56(4), 654-687.

Fulkerson, R. (1979). Four philosophies of composition. College Composition and Communication, 30(4), 343-348.

Gborsong, P. A., Afful, J. B. A., Coker, W., Osei, Y. A., Twumasi, R. A. \& Baiden, A. A. (2015). A needs analysis of undergraduate students of communicative skills: The case of tertiary institutions in Ghana. Open Journal of Modern Linguistics, 5, 413424.

Hunt, S., Wright, A., \& Simonds, C. (2014). Securing the future of communication education: Advancing an advocacy and research agenda for the 21st century. Communication Education, 63(4), 449-461.

Maars, S. (2006). The emergence of communication studies in Australia as "curriculum idea". Australian Journal of Communication, 33(2/3), 43-62. 
Morreale, S., Hungenberg, L., \& Worley, D. (2006). The basic communication course at US colleges and universities in the 21st century: Study VIII. Communication Education, 55(4), 415-437.

Morreale, S. P., \& Backlund, P. M. (2002). Communication curricula: History, recommendations, resources. Communication Education, 51(1), 2-18.

Nwosu, P. O. (2014). Indexing for communication journals in Africa: The global knowledge economy and the politics of knowledge distribution. Africa Media Research, 14(1/2), 39-48.

Nainby, K. (2010). The philosophical and methodological foundations of communication education. In D. L. Fassett \& J. T. Warren (Eds.), The Sage handbook of communication and instruction (pp. 11-32). Los Angeles: Sage.

Odhiambo, L. O. Boafo, S. T. K., Aznar, A., McClain, J., \& Sy, C. (2002). Communication education and training in the 21st century: The African context. In S. T. K. Boafo (Eds.), Communication training in Africa: Model curricula (pp. 7-14). UNESCO: Panoply.

Olsen, R., Weber, D., \& Trimbe, F. (2002). Cornerstones and capstones: A case study on the value of a holistic core in the discipline of communication studies. Communication Education, 51(1), 65-80.

Olson, G. A. (1998). Encountering the other: Postcolonial theory and composition scholarship. JAC: A Journal of Rhetoric, Writing, Culture, and Politics, 18, 45-55.

Porter, J. E., Sullivan, P., Blythe, S. Grabill, J. T., \& Miles, L. (2000). Institutional critique: A rhetorical methodology for change. College Composition and Communication, 51(4), 610-642.

Pratt, M. L. (1991). Arts of the contact zone. Profession, 33-40.

Street, B. (2003). What's "new" in new literacy studies? Critical approaches to literacy in theory and practice. Current Issues in Comparative Education, 5(2), 77-91.

Taba, H. (1962). Curriculum development: Theory and practice. New York: Harcourt, Brace and World.

Taylor, D. S., Nwosu, P. O., \& Mutua-Kombo, E. (2004). Communication studies in Africa: The case for a paradigm shift for the 21st century. Africa Media Review, $12(2), 1-23$.

Thompson, B. (2007). The syllabus as a communication document: Constructing and presenting the syllabus. Communication Education, 56(1), 54-71.

Tracy, S. J. (2013). Field roles, fieldnotes, and field focus. Qualitative research methods: Collecting evidence, crafting analysis, communicating impact. Malden, MA: WileyBlackwell.

Valenzano III, J. M., Wallace, S. P., \& Sherwyn P. M. (2014). Consistency and change: The (r)evolution of the basic communication course. Communication Education, 63(4), 355-365.

Waldeck, J. H., Plax, T. G., \& Kearney, P. (2010). Philosophical and methodological foundations of instructional communication. In D. L. Fassett \& J. T. Warern (Eds.), The Sage handbook of communication and instruction (pp. 161-180). Los Angeles and Washington DC: Sage.

Witt, P. (2014). The future of communication education. Communication Education, 61(1), 1-3. 